
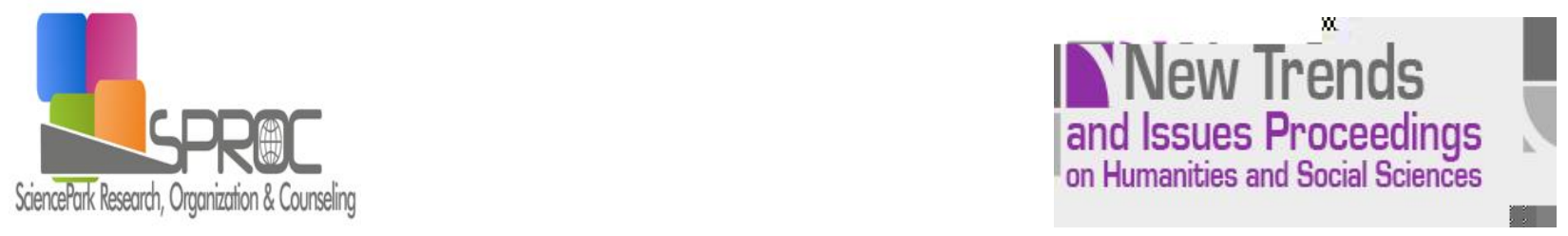

\title{
Determination Of University Student Attitudes Toward Violence
}

Hande Sahin *

Sibel Erkal

Suggested Citation:

New Trends and

Issues Proceedings on Humanities and Social Sciences

Abstract

Hande Sahin

E-mail address 
1. Introduction

2. Method

3. Data Collection 


\section{Data Evaluation}

\section{Results}

Table 1: Comparison of Student Attitudes toward Violence by Age Group

\begin{tabular}{lllll} 
Age & $n$ & Mean Rank & $x^{2}$ & $P$ \\
\hline
\end{tabular}


Table 2: Comparison of Student Attitudes toward Violence by Gender

\begin{tabular}{llllll}
\hline Gender & N & Mean Rank & U & & $P$ \\
\hline
\end{tabular}

Table 3: Comparison of Student Attitudes toward Violence by Year at University

\section{Discussion}




\section{Conclusion And Suggestions}

\section{References}

).

- (Yayinlanmamis doktora tezi) Marmara Universitesi

Journal of Clinical Psychology 56

, 11

Ogrenci Ergenlerin Siddete Yonelik Tutumlari: Yas Ve Cinsiyete Gore Bir Inceleme.

10

Aggressive behavior 26

American Journal of Preventive Medicine 20

Farkli Sosyo-Ekonomik Duzeylere Mensup Ergenlik Cagindaki Kiz Ve Erkeklerin Saldirgan Davranislariyla Ana-Baba Tutumlari Arasindaki Iliskiler.

Evlilikte Kadina Yonelik Fiziksel Siddete Iliskin Tutumlarin Yordayicilari: Celisik Duygulu Cinsiyetcilik, Sistemi Mesrulastirma ve Dini Yonelim. 
.C.U.Tip Fakultesi Dergisi, 24

Egitim ve Bilim, 37

Ergenlerde Siddet Egilimi, Yalnizlik ve Sosyal Destek

Clinical Psychology Review

Ergenlerde Baglanma ve Saldirganlik Davranislari Arasindaki Iliskinin Incelenmesi.

Gokalp Egitim Fakultesi Dergisi

, Dicle Universitesi Ziya

Insan Bilimleri Dergisi, 6

ilede Kadina Yonelik Siddet: Denizli Ili Ornegi. Uluslararasi

Universite Ogrencilerinin Siddet Egilimlerinin ve Toplumsal Cinsiyet Rollerine Iliskin Tutumlarinin Incelenmesi. Nesne, 1

The World Report On Violence And

Health

Kocaeli Universitesi 2008-2009 Akademik Yili 1.ve 6. Sinif Tip Ogrencilerinin Evlilikte Kadina Yonelik Siddete Iliskin Tutumlari.

. Journal of Psychiatric Nursing, 2

. Journal of Family Violence. 18 